\title{
Comprehensive Utilization of Filter Residue from the Preparation Process of Zeolite-Based Catalysts
}

DOI: $10.15255 / K U I .2016 .001$

KUI-15/2016

Original scientific paper

Received January 17, 2016

Accepted April 4, 2016

\author{
S.-Q. Zheng, ${ }^{a, b^{*}} L^{-}-J . H e,{ }^{a}$ S. Ren, ${ }^{a}$ H.-X. Yu, a,b and J.-C. Zhang ${ }^{a, b}$ \\ a Department of Chemistry and Chemical Engineering, Hunan Institute of Science \\ and Technology, Yueyang 414 006, Hunan, P. R. China \\ b Hunan Province Key Laboratory of Speciality Petrochemicals Catalysis and \\ Separation, Yueyang 414000, Hunan, P. R. China
}

\begin{abstract}
\| Abstract
A novel utilization method of filter residue from the preparation process of zeolite-based catalysts was investigated. Y zeolite and a fluid catalytic cracking (FCC) catalyst were synthesized from filter residue. Compared to the Y zeolite synthesized by the conventional method, the $Y$ zeolite synthesized from filter residue exhibited better thermal stability. The catalyst possessed wide-pore distribution. In addition, the pore volume, specific surface area, attrition resistance were superior to those of the reference catalyst. The yields of gasoline and light oil increased by 1.93 and $1.48 \%$, respectively. At the same time, the coke yield decreased by $0.41 \%$. The catalyst exhibited better gasoline and coke selectivity. The quality of the cracked gasoline had been improved.
\end{abstract}

$\|$ Keywords

Filter residue, catalyst factory, Y zeolite, FCC catalyst, utilization

\section{Introduction}

The main raw materials for the production of molecular sieve FCC catalyst include water glass, sodium hydroxide, aluminium hydroxide, kaolin, sulphuric acid, hydrochloric acid, liquid ammonia, ammonium chloride, and chlorinated rare earth, alkali, salt, etc. The molecular sieve FCC catalyst is prepared through three processes that involve synthesis of molecular sieve, modification of molecular sieve, and preparation of catalyst. During the above processes, a large amount of filter residue is produced. The filter residue is a mixture of amorphous silica-aluminas, zeolites $\mathrm{Y}$ and ZSM-5, composed mainly of silica, alumina, $\operatorname{Re}_{2} \mathrm{O}_{3 \prime}$ $\mathrm{Na}_{2} \mathrm{O}, \mathrm{Fe}_{2} \mathrm{O}_{3}$. The moisture content in the filter residue is above $70 \%$. Compared to kaolin, the filter residue has larger pore volume, specific surface area.

Zeolite-based catalysts manufacturers generate tens of thousands tons of catalyst filter residue each year during production, causing environmental problems that are difficult to handle. Because the filter residue is an appropriate raw material for high-value silicon/aluminium products from either crystal phase composition or main chemical elements, the method for the utilization of the filter residue was developed. ${ }^{1-4}$ Application of the filter residue was limited to extracting useful components, such as extracting active $\mathrm{SiO}_{2}$ and $\mathrm{Al}_{2} \mathrm{O}_{3}$. The filter residue is predominantly used in the field of construction materials, such as filler for

${ }^{*}$ Corresponding author: Dr. Shu-Qin Zheng

e-mail: zhengshuqin37@163.com asphalt, and production of bricks and cement. $\mathrm{NaX}$ and $4 \mathrm{~A}$ zeolite were also synthesized using these solid wastes.

The FCC catalyst is probably the most significant, mass-produced modern catalyst. $^{5-6}$ The Faujasite type $Y$ zeolite (FAU) has been widely used in the FCC catalyst as the main active component due to its high surface area, large pore size, and proper active sites. ${ }^{7-10}$

The in situ synthesised zeolites have an ideal hydrothermal stability. In situ synthesizing of zeolite can surmount the difficulty of filtration in industrial production and reduce production costs. Because the filter residue has active useful components, these components can be used for the synthesis of zeolite. We envision synthesizing zeolite $Y$ via in situ crystallization technology that enlarges utilization catalogues and quantities of industrial filter residue.

Herein, Y zeolite and an FCC catalyst were synthesized from filter residue. The physicochemical properties of synthesized zeolite and the cracking activity of the catalyst were investigated.

\section{Experimental}

\subsection{Materials}

Catalyst filter residue (CFR) was obtained from the Catalyst Factory of Sinopec in China. The filter residue was white gel. Moisture content was $77.8 \%$. The properties of CFR 
are listed in Table 1 (the composition of compounds and mixtures is expressed in terms of mass fraction).

Table 1 - Properties of catalyst filter residue (CFR)

Tablica 1 - Svojstva filtarskog ostatka katalizatora

\begin{tabular}{|c|c|c|}
\hline \multirow{5}{*}{ 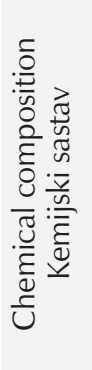 } & $w\left(\mathrm{SiO}_{2}\right) / \%$ & 65.80 \\
\hline & $w\left(\mathrm{Al}_{2} \mathrm{O}_{3}\right) / \%$ & 23.84 \\
\hline & $w\left(\mathrm{Fe}_{2} \mathrm{O}_{3}\right) / \%$ & 0.18 \\
\hline & $w\left(\mathrm{Na}_{2} \mathrm{O}\right) / \%$ & 2.15 \\
\hline & $w\left(\operatorname{Re}_{2} \mathrm{O}_{3}\right) / \%$ & 1.44 \\
\hline \multicolumn{2}{|c|}{$\begin{array}{l}\text { BET specific surface area } / \mathrm{m}^{2} \mathrm{~g}^{-1} \\
\text { specifična ploština površine po BET-u } / \mathrm{m}^{2} \mathrm{~g}^{-1}\end{array}$} & 300 \\
\hline \multicolumn{2}{|c|}{$\begin{array}{l}\text { total pore volume } / \mathrm{ml} \mathrm{g}^{-1} \\
\text { specifični obujam pora } / \mathrm{ml} \mathrm{g}^{-1}\end{array}$} & 0.91 \\
\hline \multicolumn{2}{|c|}{$\begin{array}{l}\text { average pore diameter } / \mathrm{nm} \\
\text { prosiečni promier pora } / \mathrm{nm}\end{array}$} & 10.20 \\
\hline
\end{tabular}

Sodium silicate (containing $22.6 \% \mathrm{SiO}_{2}, 7.2 \% \mathrm{Na}_{2} \mathrm{O}$ ) and sodium metaaluminate (containing $20.5 \% \mathrm{Na}_{2} \mathrm{O}, 3.1 \%$ $\mathrm{Al}_{2} \mathrm{O}_{3}$ ) were obtained from Hunan Juli Catalyst Co., Ltd.

\subsection{Zeolite synthesis}

A mixture of sodium silicate, sodium hydroxide, zeolite initiator (the mass ratio of oxides $\mathrm{Na}_{2} \mathrm{O}, \mathrm{Al}_{2} \mathrm{O}_{3}, \mathrm{SiO}_{2}$, $\mathrm{H}_{2} \mathrm{O}$ is $16: 1: 15: 320$ ) and filter residue was mixed in sequence. The synthesis of zeolite $\mathrm{Y}$ involved an inorganic reaction with a stoichiometry of $\mathrm{Na}_{2} \mathrm{O}: \mathrm{SiO}_{2}: \mathrm{Al}_{2} \mathrm{O}_{3}: \mathrm{H}_{2} \mathrm{O}$ $=2.9: 1: 4.8: 110$. The mixture was agitated for $1 \mathrm{~h}$ followed by crystallization in a reactor, and heated to $95{ }^{\circ} \mathrm{C}$ for $16-20 \mathrm{~h}$. The obtained solid product $(\mathrm{YZ})$ was filtered and washed until the $\mathrm{pH}$ value of filtered water dropped to 9 , and then oven-dried at $120{ }^{\circ} \mathrm{C}$ for $4 \mathrm{~h}$. $\mathrm{YZ}$ was exchanged one or more times with approximately 10 to $30 \%$ (in mass) of ammonium chloride to replace the sodium, and then exchanged with $3 \%$ (in mass) of lanthanum chloride, followed by calcination at $600{ }^{\circ} \mathrm{C}$ with $100 \%$ steam for $2 \mathrm{~h}$ to produce modified $\mathrm{YZ}$.

The reference NaY zeolite synthesized by the conventional method involved the following steps: A reaction mixture was prepared by mixing the zeolite initiator with sodium silicate, and adding sodium aluminate solution. The mixture was stirred vigorously, and an aluminium sulphate solution was added to the mixture. The mixture was then heated at a temperature of $95^{\circ} \mathrm{C}$. After 28 hours, the product was filtered and washed. The X-ray diffraction analysis showed an excellent pattern characteristic of zeolite $Y$.

\subsection{Catalyst preparation}

Deionized water, kaolin, pseudo-boehmite were mixed with a hydrochloric acid solution and stirred at a rate sufficient to form a uniform slurry. The mixture was stirred for $2 \mathrm{~h}$. Alumina sol and modified $\mathrm{YZ}$ were subsequently added, the mixture was stirred at room temperature for $1-2 \mathrm{~h}$. The mass ratio of deionized water, kaolin, pseudo-boehmite, alumina sol and modified YZ was $200: 40: 13: 12: 35$. The catalyst (CAT) with a particle size of $0-150 \mu \mathrm{m}$ was produced by spray drying, then calcined at $500{ }^{\circ} \mathrm{C}$ for $0.5 \mathrm{~h}$, washed with warm water, and dried.

The reference catalyst (RCAT) was a residue FCC catalyst obtained from a domestic refinery with a specific surface area of $283 \mathrm{~m}^{2} \mathrm{~g}^{-1}$ and a specific pore volume of $0.22 \mathrm{~cm}^{3} \mathrm{~g}^{-1}$. $^{11}$

\subsection{Sample characterization}

Relative crystallinity, silica/alumina, crystalline unit cell size and phase of samples were recorded on a Rigaku Ultimi IV diffractometer using $\mathrm{Cu}-\mathrm{K} \alpha$ radiation $(\lambda=1.54056 \AA)$ at an operating voltage and current of $40 \mathrm{kV}$ and $30 \mathrm{~mA}$, respectively. The samples were scanned at $0.2^{\circ} \mathrm{min}^{-1}$. The IR spectra were recorded on an AVATAR 370 FT-IR spectrometer in the range from 400 to $2000 \mathrm{~cm}^{-1}$. The acidity properties of samples were determined using pyridine adsorption method. The FTIR spectra exhibited peaks at 1540 and $1450 \mathrm{~cm}^{-1}$, suggesting the existence of Brønsted acid sites, and Lewis acid sites, respectively. The acid strength distributions were quantitatively calculated from the pyridine adsorbed IR spectra at 200 and $400{ }^{\circ} \mathrm{C}$ (representing total acid amount and strong acid amount, respectively). ${ }^{8}$ The morphology and size of the samples were determined using scanning electron microscopy (SEM) (JEOL JSM-6360) after coating with an Au-evaporated film. The specific surface areas, specific pore volumes, and pore size distributions were measured on an ASAP 2020 sorptometer using adsorption and desorption isotherm plots at $77 \mathrm{~K}$. A Malvern Micro-P particle-size distribution analyser was used for determining the size distribution in the samples. The attrition index of the catalyst was determined using an attrition index analyser by the air injection method.

\subsection{Catalytic properties evaluation}

The catalytic performance of the catalyst was evaluated on an advanced catalyst evaluation bench unit (ACE, Kayser Corp.). The evaluation conditions were as follows: reactor temperature of $520{ }^{\circ} \mathrm{C}$, catalyst-to-oil mass ratio of 6.0 and WHSV of $19 \mathrm{~h}^{-1}$. Prior to evaluation, the catalyst was steam-deactivated at $800{ }^{\circ} \mathrm{C}$ for $17 \mathrm{~h}$ with $100 \%$ steam. The feedstock oil consisted of a mixture of $70 \%$ vacuum gas oil (VGO) and $30 \%$ vacuum tower bottom (VTB), and its properties are listed in Table 2. 
Table 2 - Properties of feedstock oil

Tablica 2 - Svojstva sirovine za FCC

\begin{tabular}{c|c}
\hline $\begin{array}{c}\text { Variable } \\
\text { Veličina }\end{array}$ & $\begin{array}{c}\text { Value } \\
\text { Vrijednost }\end{array}$ \\
\hline $\begin{array}{c}\text { density }\left(20{ }^{\circ} \mathrm{C}\right) / \mathrm{gcm}^{-3} \\
\text { gustoća }\left(20{ }^{\circ} \mathrm{C}\right) / \mathrm{g} \mathrm{cm}^{-3}\end{array}$ & 0.9222 \\
viscosity $\left(50{ }^{\circ} \mathrm{C}\right) / \mathrm{mm}^{2} \mathrm{~s}^{-1}$ & 79.48 \\
viskoznost $\left(50{ }^{\circ} \mathrm{C}\right) / \mathrm{mm}^{2} \mathrm{~s}^{-1}$ & 3.8 \\
Conradson carbon residue $\%$ & \\
Conradsonov koksni ostatak $/ \%$ & temperature $/{ }^{\circ} \mathrm{C}$ \\
\hline distillation fraction & temperatura $/{ }^{\circ} \mathrm{C}$ \\
destilacijska frakcija & 286 \\
initial point & 350 \\
početna točka & 401 \\
$10 \%$ & 455 \\
$30 \%$ & 500 \\
$50 \%$ & 556 \\
$70 \%$ & $>556$ \\
$90 \%$ & \\
end point &
\end{tabular}

\section{Results and discussion}

\subsection{Structure of zeolite}

The chemical composition of CFR was mainly composed of $\mathrm{SiO}_{2}$ and $\mathrm{Al}_{2} \mathrm{O}_{3}$, and had higher specific surface area and specific pore volume (Table 1). Using this CFR as raw material, the typical zeolite $Y$ can be obtained. The intensity and shape of the peaks in Fig. 1 indicated that the sample was pure zeolite Y. Under the optimum conditions, the synthesized $\mathrm{Y}$ zeolite (YZ) had a relative crystallinity of $71.5 \%$, and a silica/alumina amount ratio of 5.7 , respectively. Fig. 2 displayed that the sizes of the $Y$ zeolite particles were $0.2-0.5 \mu \mathrm{m}$, which indicated that smaller crystals had agglomerated with the larger particles.

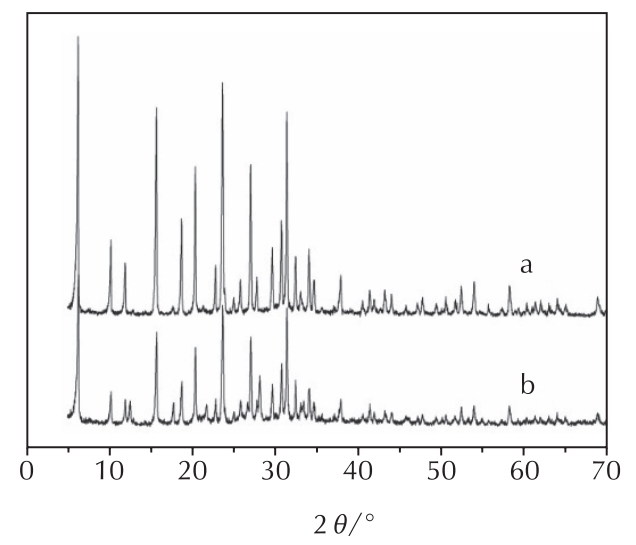

Fig. 1 - XRD patterns of (a) NaY, (b) YZ

Slika 1 - Rendgenski difraktogrami (a) NaY, (b) YZ
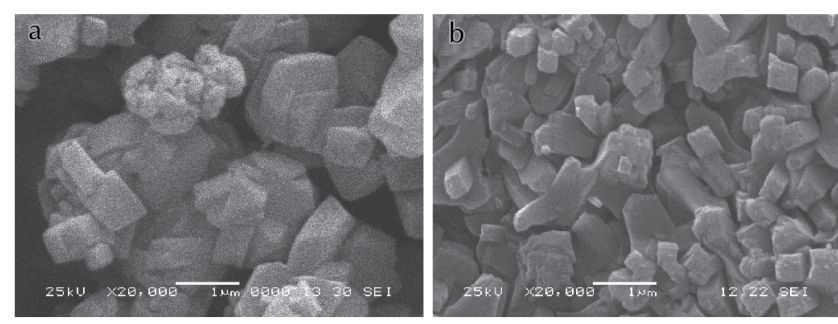

Fig. 2 - SEM images of (a) NaY, (b) YZ Slika 2 - Slike SEM (a) NaY, (b) YZ

Fig. 3 shows the nitrogen adsorption-desorption isotherms and pore-size distribution of $Y Z$. Typical type IV isotherms of $Y Z$ confirmed the presence of mesopores and macropores. $Y Z$ possessed a wide pore distribution, the distribution was concentrated on approximately 3.0, 4.0, and $5-10 \mathrm{~nm}$, respectively. The total specific surface area of $Y Z$ reached a maximum of $640 \mathrm{~m}^{2} \mathrm{~g}^{-1}$ and its external specific surface area was $76 \mathrm{~m}^{2} \mathrm{~g}^{-1}$ (Table 3). The fraction of the external surface area in total surface area was $11.9 \%$ (Table 3), which was much larger than that of $Y$ zeolite synthesized by the conventional method, its fraction of external surface area in total surface area was only $4.4 \%$.
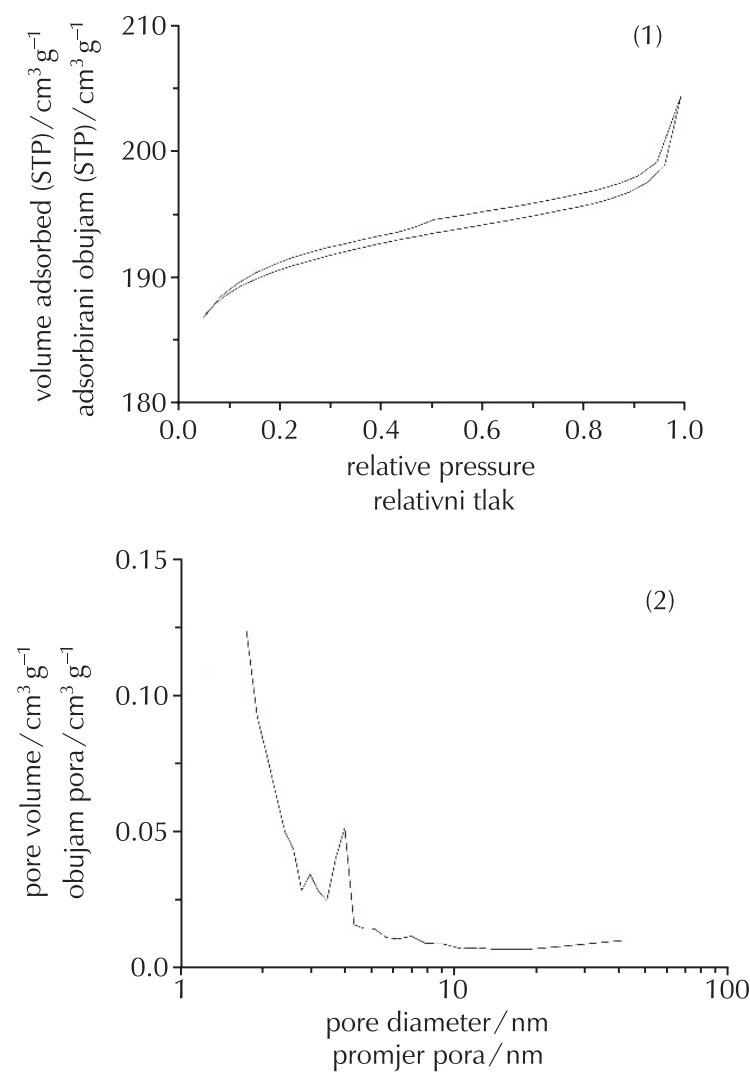

Fig. 3 - Nitrogen adsorption-desorption isotherms (1), and pore size distribution (2) of $\mathrm{YZ}$

Slika 3 - Adsorpcijsko-desorpcijske izoterme dušika (1) i distribucija veličina pora (2) zeolita YZ 
Table 3 - Properties of $\mathrm{YZ}$ and NaY

Tablica 3 - Svojstva zeolita YZ i NaY

\begin{tabular}{|c|c|c|}
\hline $\begin{array}{l}\text { Property } \\
\text { Svojstvo }\end{array}$ & $\mathrm{YZ}$ & $\mathrm{NaY}$ \\
\hline $\begin{array}{l}\text { BET specific surface area } / \mathrm{m}^{2} \mathrm{~g}^{-1} \\
\text { specifična ploština površine po BET-u } / \mathrm{m}^{2} \mathrm{~g}^{-1}\end{array}$ & 640 & 722 \\
\hline $\begin{array}{l}\text { BJH specific surface area } / \mathrm{m}^{2} \mathrm{~g}^{-1} \\
\text { specifična ploština površine po BJH-u } / \mathrm{m}^{2} \mathrm{~g}^{-1}\end{array}$ & 88 & 47 \\
\hline $\begin{array}{l}\text { micropore specific surface area } / \mathrm{m}^{2} \mathrm{~g}^{-1} \\
\text { specifična ploština površine mikropora } / \mathrm{m}^{2} \mathrm{~g}^{-1}\end{array}$ & 564 & 690 \\
\hline $\begin{array}{l}\text { external specific surface area } / \mathrm{m}^{2} \mathrm{~g}^{-1} \\
\text { vanjska specifična ploština površine } / \mathrm{m}^{2} \mathrm{~g}^{-1}\end{array}$ & 76 & 32 \\
\hline $\begin{array}{l}\text { total pore volume } / \mathrm{mlg}^{-1} \\
\text { specifični ukupni obujam pora } / \mathrm{mlg}^{-1}\end{array}$ & 0.38 & 0.34 \\
\hline $\begin{array}{l}\text { micropore pore volume } / \mathrm{mlg}^{-1} \\
\text { specifični obujam mikropora } / \mathrm{mlg}^{-1}\end{array}$ & 0.29 & 0.31 \\
\hline $\begin{array}{l}\text { BJH pore volume } / \mathrm{mlg}^{-1} \\
\text { obujam BJH pora } / \mathrm{mlg}^{-1}\end{array}$ & 0.10 & 0.036 \\
\hline $\begin{array}{l}\text { average pore diameter } / \mathrm{nm} \\
\text { prosječni promjer pora } / \mathrm{nm}\end{array}$ & 3.86 & 2.71 \\
\hline $\begin{array}{l}\text { unit cell size/nm } \\
\text { veličina jedinične ćelije/nm }\end{array}$ & 2.472 & 2.468 \\
\hline
\end{tabular}

Fig. 4 shows TG-DTA spectra of YZ. When calcination temperature was up to $920^{\circ} \mathrm{C}$, the skeleton of $\mathrm{YZ}$ collapsed, while skeleton collapse occurred at about $850{ }^{\circ} \mathrm{C}$ for zeolite synthesized by the common route. ${ }^{12} \mathrm{YZ}$ exhibited high thermal stability. The main reason is that the $Y Z$ zeolite led to wide distribution of particles, which reduced the instability due to low coordination of zeolite synthesized by the common route. ${ }^{13}$

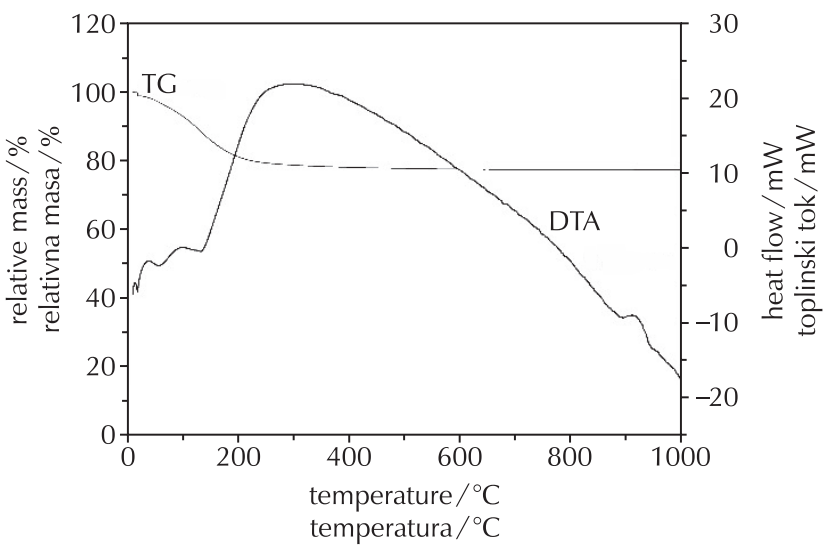

Fig. 4 - TG-DTA spectra of YZ

Slika 4 - TG-DTA-spektar zeolita YZ

\subsection{Characterization of catalyst}

The properties of the catalyst and the reference catalyst are summarized in Table 4. Comparably, the catalyst has a much larger BET surface area, micropore surface area, total pore volume, and average pore diameter. There were more surface active atoms on the surface compared to the reference catalyst. Therefore, reactant molecules easily get close to the active sites, and thus improve the utilization rate of active sites, leading to higher conversion by the catalysts.

Table 4 - Properties of CAT and RCAT

Tablica 4 - Svojstva katalizatora CAT i RCAT

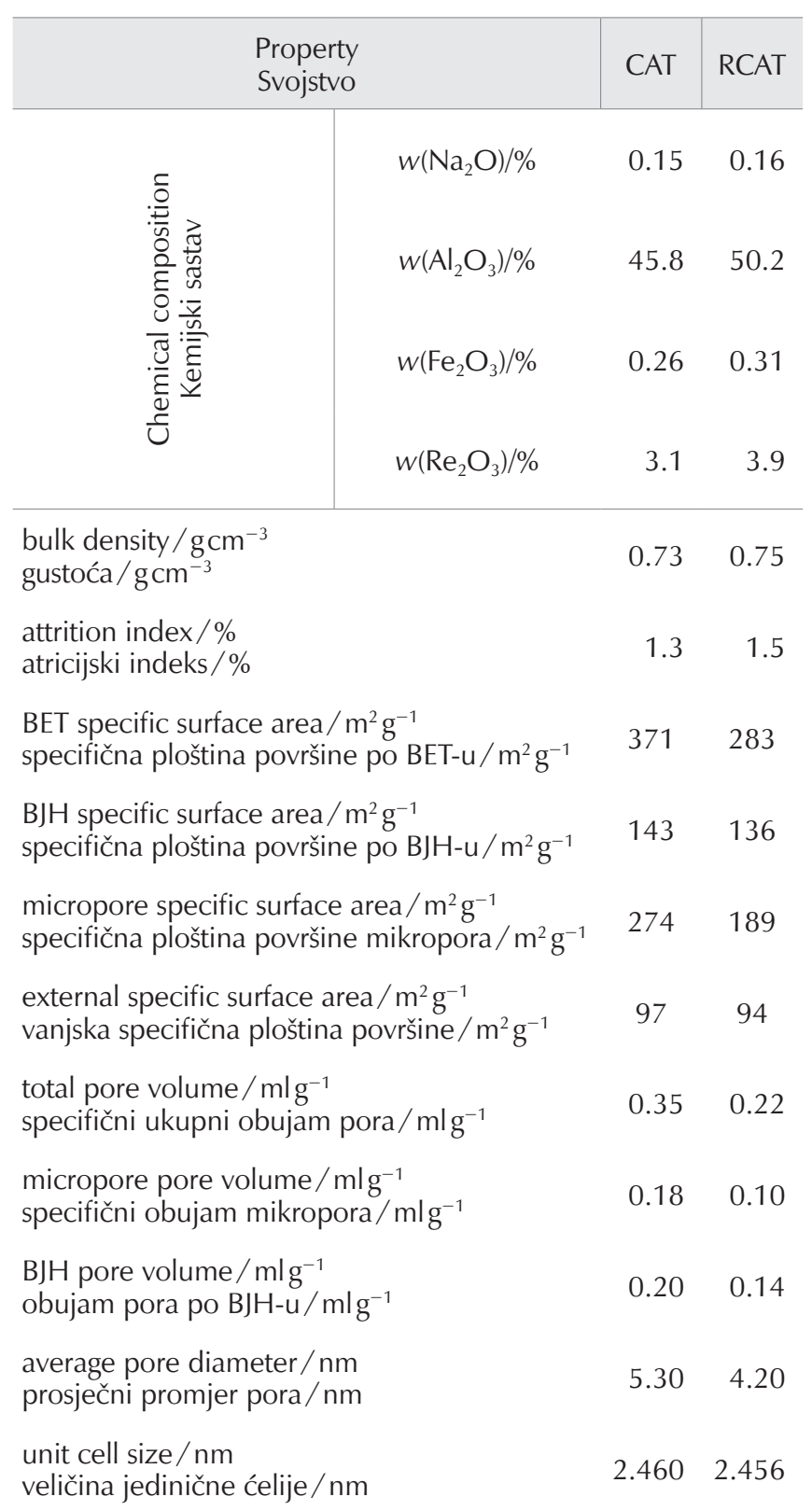

Fig. 5 shows the nitrogen adsorption-desorption isotherms and pore-size distribution of CAT and RCAT. In Fig. 5 (1), 
the isotherms of CAT had a steeper drop and a larger hysteresis loop than RCAT, indicating that larger pores existed in CAT. In Fig. 5 (2), the distribution of CAT appeared from approximately 4.0 to $100 \mathrm{~nm}$, a broad distribution was observed in the pore diameter range $>60 \mathrm{~nm}$, signifying the existence of macropores, and RCAT was observed at approximately $4.0 \mathrm{~nm}$. These results confirmed the hierarchical pore structure of CAT. The catalysts with hierarchical pore structure have the advantages of microporous materials and meso-macroporous materials. Hierarchical materials possessing at least two levels of porosity can reduce diffusion limitations in reactions catalysed by microporous zeolites, which have good selectivity and mass transfer capability. ${ }^{14}$
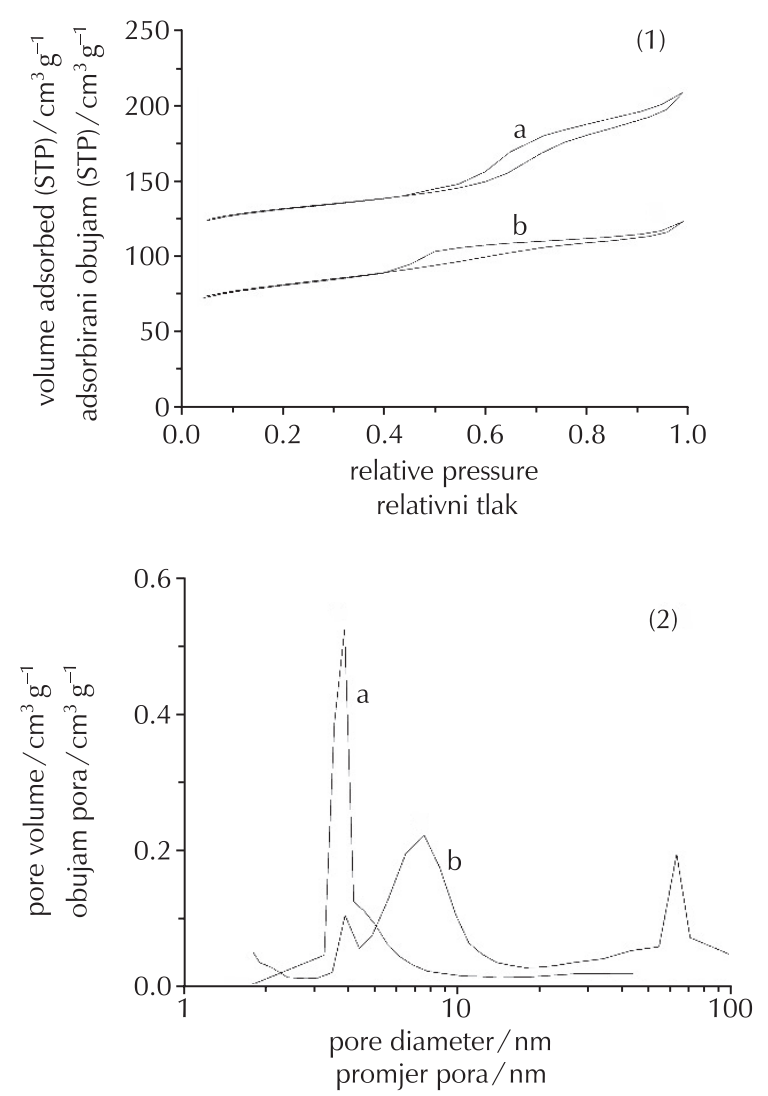

Fig. 5 - Nitrogen adsorption-desorption isotherms (1), and pore size distribution (2) for (a) CAT, and (b) RCAT

Slika 5 - Adsorpcijsko-desorpcijske izoterme dušika (1) i distribucija veličina pora (2) katalizatora (a) CAT i (b) RCAT

The determined acidities of CAT and RCAT are listed in Table 4 and Fig. 6. Comparably, the strong Brønsted acid and the weak Lewis acid amounts of CAT were higher. The more Brønsted acid sites are ascribed to the better crystal structure of $Y$ zeolite synthesized from filter residue. Weak Lewis acid sites and higher Brønsted acid sites are helpful in improving catalytic performance..$^{15-16}$
Table 5 - Acidic properties of CAT and RCAT (relative strength of absorbance bands)

Tablica 5 - Kiselinska svojstva katalizatora CAT i RCAT (relativna jakost apsorpcijskih signala)

\begin{tabular}{l|c|c|c|c}
\hline \multirow{2}{*}{$\begin{array}{l}\text { Samples } \\
\text { Uzorci }\end{array}$} & \multicolumn{2}{|c|}{ CAT } & \multicolumn{2}{c}{ RCAT } \\
\cline { 2 - 5 } & Brønsted & Lewis & Brønsted & Lewis \\
\hline $\begin{array}{l}\text { weak acid amount } \\
\text { slabo kisela aktivna } \\
\text { mjesta }\end{array}$ & 10.4 & 9.2 & 7.6 & 8.5 \\
$\begin{array}{l}\text { strong acid amount } \\
\text { jako kisela aktivna } \\
\text { mjesta }\end{array}$ & 9.3 & 7.9 & 4.5 & 8.2 \\
$\begin{array}{l}\text { total acid amount } \\
\text { ukupna kisela } \\
\text { aktivna mjesta }\end{array}$ & 19.7 & 17.1 & 12.1 & 16.7 \\
\hline
\end{tabular}

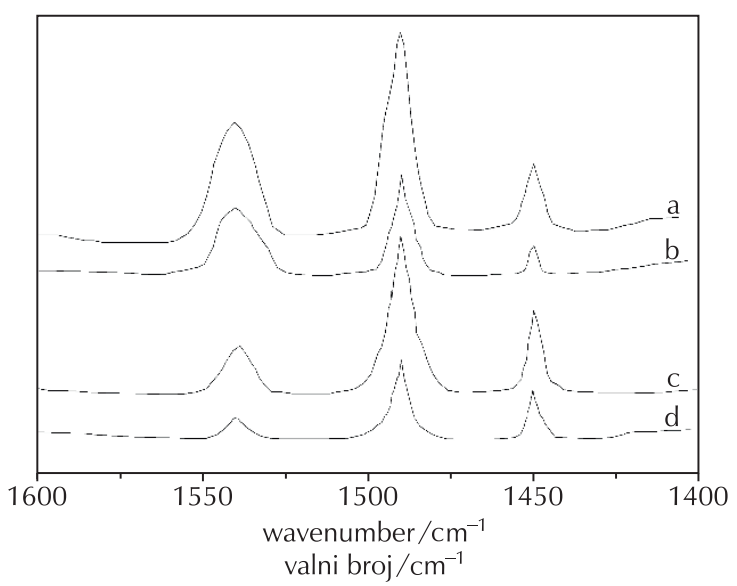

Fig. 6 - FTIR spectra of: (a) CAT desorbed at $200{ }^{\circ} \mathrm{C}$, (b) CAT desorbed at $400{ }^{\circ} \mathrm{C}$, (c) RCAT desorbed at $200{ }^{\circ} \mathrm{C}$, and (d) RCAT desorbed at $400{ }^{\circ} \mathrm{C}$

Slika 6 - FTIR-spektri: (a) CAT desorbiran pri $200{ }^{\circ} \mathrm{C}$, (b) CAT desorbiran pri $400{ }^{\circ} \mathrm{C}$, (c) RCAT desorbiran pri $200{ }^{\circ} \mathrm{C}$ i (d) RCAT desorbiran pri $400{ }^{\circ} \mathrm{C}$

\subsection{Catalytic properties evaluation}

The results of catalytic performance for CAT and RCAT are shown in Table 6. It can be seen that compared with the RCAT, the CAT can increase gasoline yield, conversion and liquid yields (LPG + gasoline + LCO) by 1.93, 2.27 and $2.29 \%$, respectively. At the same time, coke yield is decreased by $0.41 \%$. Table 7 shows the cracked gasoline compositions over the two catalyst. Comparably, the olefin content of CAT reduced by $2.98 \%$ with the research octane number, and motor octane number of gasoline increased by 0.7 and 0.5 . These excellent catalytic performances can be attributed to the novel utilization technology of industrial filter residue. 
Table 6 - Product distribution of CAT

Tablica 6 - Proizvodna distribucija CAT-a

\begin{tabular}{|c|c|c|c|}
\hline $\begin{array}{l}\text { Product } \\
\text { Proizvod }\end{array}$ & CAT & RCAT & $\begin{array}{l}\text { Difference } \\
\text { Razlika }\end{array}$ \\
\hline \multicolumn{4}{|c|}{$\begin{array}{l}\text { product yield by mass } / \% \\
\text { iskorištenje proizvoda po masi / \% }\end{array}$} \\
\hline $\begin{array}{l}\text { dry gas } \\
\text { suhi plin }\end{array}$ & 2.17 & 2.23 & -0.06 \\
\hline LPG & 15.43 & 14.62 & +0.81 \\
\hline $\begin{array}{l}\mathrm{C}_{5+} \text { gasoline } \\
\text { benzin } \mathrm{C}_{5+}\end{array}$ & 47.71 & 45.78 & +1.93 \\
\hline LCO & 18.80 & 19.25 & -0.45 \\
\hline $\begin{array}{l}\text { heavy oil } \\
\text { teško ulje }\end{array}$ & 8.95 & 10.77 & -1.82 \\
\hline $\begin{array}{l}\text { coke } \\
\text { koks }\end{array}$ & 6.94 & 7.35 & -0.41 \\
\hline $\begin{array}{l}\text { conversion } \\
\text { konverzija }\end{array}$ & 72.25 & 69.98 & +2.27 \\
\hline $\begin{array}{l}\text { light oil } \\
\text { lako ulje }\end{array}$ & 66.51 & 65.03 & +1.48 \\
\hline $\begin{array}{l}\text { total liquid } \\
\text { ukupno kapljevine }\end{array}$ & 81.94 & 79.65 & +2.29 \\
\hline \multicolumn{4}{|c|}{$\begin{array}{c}\text { product selectivity (yield-to-conversion ratio) } \\
\text { selektivnost (omjer iskorištenja i ukupne konverzije) }\end{array}$} \\
\hline $\begin{array}{l}\text { dry gas } \\
\text { suhi plin }\end{array}$ & 0.030 & 0.032 & -0.002 \\
\hline $\begin{array}{l}\text { gasoline } \\
\text { benzin }\end{array}$ & 0.66 & 0.65 & +0.01 \\
\hline $\begin{array}{l}\text { coke } \\
\text { koks }\end{array}$ & 0.096 & 0.10 & -0.004 \\
\hline
\end{tabular}

Table 7 - PONA analyses and gasoline octane number Tablica 7 - Analiza PONA i oktanski broj benzina

\begin{tabular}{|c|c|c|c|}
\hline $\begin{array}{l}\text { Product } \\
\text { Proizvod }\end{array}$ & CAT & RCAT & $\begin{array}{l}\text { Difference } \\
\text { Razlika }\end{array}$ \\
\hline $\begin{array}{l}\text { components } \\
\text { komponente }\end{array}$ & \multicolumn{3}{|c|}{$\begin{array}{l}\text { volume fraction } / \% \\
\text { obujamski udjel } / \%\end{array}$} \\
\hline $\begin{array}{l}\text { normal paraffins } \\
\text { normalni parafini }\end{array}$ & 3.87 & 3.95 & -0.08 \\
\hline $\begin{array}{l}\text { branched-chain paraffins } \\
\text { parafini razgranatog lanca }\end{array}$ & 24.91 & 23.24 & +1.67 \\
\hline $\begin{array}{l}\text { olefins } \\
\text { olefini }\end{array}$ & 19.75 & 22.73 & -2.98 \\
\hline $\begin{array}{l}\text { naphthenes } \\
\text { nafteni }\end{array}$ & 9.42 & 9.56 & -0.14 \\
\hline \multirow[t]{2}{*}{$\begin{array}{l}\text { aromatics } \\
\text { aromati }\end{array}$} & 42.05 & 40.52 & +1.53 \\
\hline & \multicolumn{3}{|c|}{$\begin{array}{l}\text { octane number } \\
\text { oktanski broj }\end{array}$} \\
\hline $\begin{array}{l}\text { research octane number } \\
\text { istraživački oktanski broj }\end{array}$ & 91.8 & 91.1 & +0.7 \\
\hline $\begin{array}{l}\text { motor octane number } \\
\text { motorni oktanski broj }\end{array}$ & 80.9 & 80.4 & +0.5 \\
\hline
\end{tabular}

\section{Conclusion}

A new utilization technology of the filter residue has been successfully developed. Zeolite $Y$ was synthesized from filter residue and the characterization results showed that $Y$ zeolite had a relative crystallinity higher than $70 \%$ with a silica/alumina amount ratio of 5.7, as well as better hydrothermal stability. The as-made FCC catalyst had moderate acidity, and an advantageous pore system comprising micropores, mesopores, and macropores, and then showed excellent catalytic performances on activity, bottoms cracking ability, and good yield of valuable products in heavy crude oil processing. In comparison to the reference catalyst, the yields of the gasoline and light oil increased by 1.93 and $1.48 \%$, respectively, and the olefin content in the cracked gasoline reduced by $2.98 \%$, while the research octane number increased by 0.7 .

\section{ACKNOWLEDGMENT}

This work was financially supported by the National Natural Science Foundation of China (No. 21371055), Hunan provincial Colleges and Universities Innovation Platform Open Fund Project (No. 15K049).

\section{List of abbreviations and symbols Popis kratica i simbola}

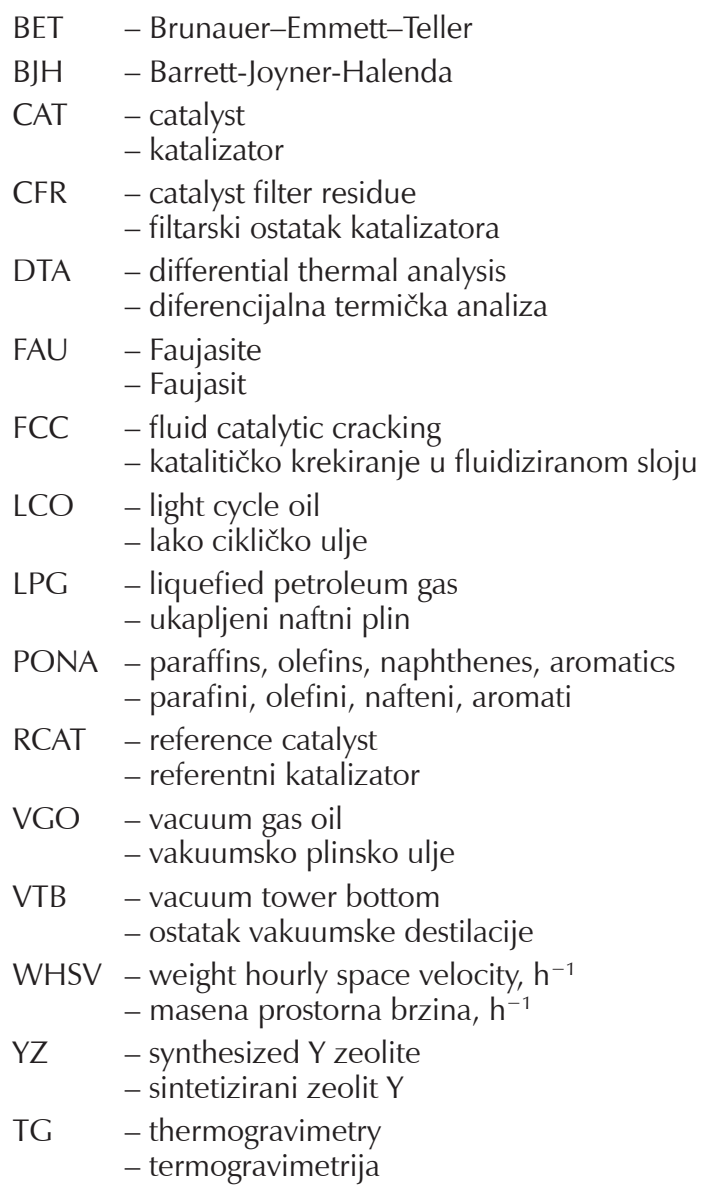




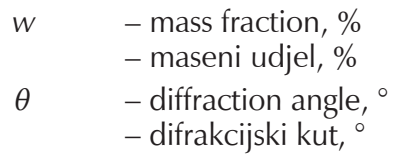

\section{References \\ Literatura}

1. L. Y. Liu, T. Du, G. Li, F. Yang, S. Che, Using one waste to tackle another: Preparation of a $\mathrm{CO}_{2}$ capture material zeolite $X$ from laterite residue and bauxite, J. Haz. Mat. 278 (2014) 551-558, doi: http://dx.doi.org/10.1016/j.jhazmat.2014.06.041.

2. X. Qi, M. Liu, Z. Chen, R. Liang, Preparation and properties of diatomite composite superabsorbent, Polymer. Adv. Tech. 18 (2007) 184-193, doi: http://dx.doi.org/10.1002/pat.847.

3. P.-J. Miao, J. Zhou, J.-L. He Jn, L.-F. Lv, Treatment of solid wastes generated in production of catalytic cracking catalyst, Qilu Petrochem. Technol. 38 (2010) 308-310.

4. E. Furimsky, S. E. Massoth, Regeneration of hydroprocessing catalysts, Catal. Today 17 (1993) 537-659, doi: http://dx. doi.org/10.1016/0920-5861(93)80056-7.

5. E. Furimsky, Spent refinery catalysts: environment, safety and utilization, Catal. Today 30 (1996) 223-286, doi: http://dx. doi.org/10.1016/0920-5861(96)00094-6.

6. M. E. Hartman, in B. van Keulen (ed.), Akzo Catalysts Symposium, Fluid Catalytic Cracking, Akzo Chemicals Division, Amersfort, The Netherlands, 1991, pp. 1-10.

7. A. Humphries, S. J. Yanik, P. H. Desai, L. A. Gerritsen, P. O'Connor, in B. van Keulen (ed.), Akzo Catalysts Symposium, Fluid Catalytic Cracking, Akzo Chemicals Division, Amersfort, The Netherlands, 1991, pp. 125-138.
8. H. H. Liu, J. T. Ma, X. H. Ga, Synthesis, characterization and evaluation of a novel resid FCC catalyst based on in situ synthesis on kaolin microspheres, Catal. Lett. 110 (2006) 229234, doi: http://dx.doi.org/10.1007/s10562-006-0113-z.

9. K. Tanabe, W. F. Hölderich, Industrial application of solid acid-base catalysts, Appl. Catal. A 181 (1999) 399-434, doi: http://dx.doi.org/10.1016/S0926-860X(98)00397-4.

10. P. Wang, B.-J. Shen, J.-S. Gao, Synthesis of MAZ/ZSM-5 composite zeolite and its catalytic performance in FCC gasoline aromatization, Catal. Commun. 8 (2007) 1161-1166, doi: http://dx.doi.org/10.1016/j.catcom.2006.10.021.

11. S. Q. Zheng, L. J. He, H. Yao, S. Ren, H. X. Yu, J. Zhang, Synthesis and application of a zeolite containing composite material made from spent FCC Catalyst, China Pet. Process. Pet. Technol. 17 (2015) 46-54.

12. X. M. Liu, L. Li, T. T. Yang, Z. F. Yan, Zeolite Y synthesized with FCC spent catalyst fines: particle size effect on catalytic reactions, J. Porous. Mater. 19 (2012) 133-139, doi: http://link. springer.com/article/10.1007/s10934-011-9534-1.

13. H. H. Liu, H. J. Zhao, X. H. Ga, J. T. Ma, A novel FCC catalyst via in situ overgrowth of $\mathrm{NaY}$ zeolite on kaolin microspheres for maximizing propylene yield, Catal. Today. 125 (2007) 163168, doi: http://dx.doi.org/10.1016/j.cattod.2007.05.005.

14. K. Zhang, M. L. Ostraat, Innovations in hierarchical zeolite synthesis, Catal. Today. 264 (2016) 3-15, doi: http://dx.doi. org/10.1016/j.cattod.2015.08.012.

15. T. Takahashi, K. Ueno, T. Kai, Vapor phase reaction of cyclohexanone oxime over boria modified HSZM-5 zeolites, Can. J. Chem. Eng. 69 (1991) 1096-1099, doi: http://dx.doi. org/10.1002/cjce.5450690508.

16. P. O'Sullivan, L. Forni, B. K. Hodnett, The role of acid site strength in the Beckmann rearrangement, Ind. Eng. Chem. Res. 40 (2001) 1471-1475, doi: http://dx.doi.org/10.1021/ ie000673q. 


\title{
SAŽETAK
}

\section{Potpuno iskorištavanje taloga preostalog nakon priprave zeolitskog katalizatora}

\author{
Shu-Qin Zheng, ${ }^{a, b^{*}}$ Li-Jun He, ${ }^{a}$ Shao Ren, ${ }^{a}$ Hong-Xia Yu a,b i Jian-Ce Zhanga,b
}

Proučena je upotreba taloga preostalog nakon priprave katalizatora baziranog na zeolitima. Od taloga su pripravljeni zeolit Y i katalizator za katalitičko krekiranje u fluidiziranom sloju (FCC).

Ovako sintetiziran zeolit $Y$ termički je stabilniji u odnosu na zeolit $Y$ sintetiziran konvencionalnom metodom. Katalizator ima široku distribuciju veličine pora. U odnosu na referentni katalizator pokazuje veći obujam pora i specifičnu površinu te bolju otpornost na atriciju. Iskorištenje benzina i lakog ulja povećalo se za 1,93 i 1,48 \%, a koksa smanjilo za 0,41 \%. Katalizator je pokazao bolju selektivnost s obzirom na benzin i koks, a poboljšala se kvaliteta krekiranog benzina.

Ključne riječi

Filtarski talog, tvornica katalizatora, zeolit Y, katalizator FCC, iskoristivost

a Department of Chemistry and Chemical Engineering, Hunan Institute of Science and Technology, Yueyang 414 006, Hunan, Kina ${ }^{\mathrm{b}}$ Hunan province Key Laboratory of Speciality Petrochemicals Catalysis and Separation, Yueyang 414 000, Hunan, Kina
Izvorni znanstveni rad Prispjelo 17. siječnja 2016. Prihvaćeno 4. travnja 2016. 